\title{
An Overview of Peer-Assessment: The Benefits and Importance
}

\author{
Amirreza Karami \& Amir Rezaei \\ Department of Language Teaching, Zanjan Branch, Islamic Azad University, Zanjan, Iran \\ E-mail: Karamiar20@gmail.com
}

Received: May 2, 2015 Accepted: June 23, 2015 Published: June 24, 2015

doi:10.5296/jsel.v3i1.7889 URL: http://dx.doi.org/10.5296/jsel.v3i1.7889

\begin{abstract}
Learner's language proficiency and knowledge need to be evaluated based on different methods (Orsmond, Merry \& Reiling (2000); Pope 2005). Authentic assessment attained by using real evidence is also achievable (Barbera 2009 and Barrett 2007). This authentic assessment can be achieved through cooperation between teachers and learners. Peerassessment as one of these alternative assessments seeks a new way for authentic assessment. Importance of peer-assessment is also reported in previous studies. Although there are some unrecognized aspects, peer-assessment is considered to be effective (Shepard 2000 and Topping 1998).
\end{abstract}

Keywords: Peer-assessment, alternative assessment, positive influence 


\section{Introduction}

In modern educational settings, the importance of innovative assessment on learning efficiency has been emphasized (McDowell 1995). One of the main purpose of modern education is making attempts to emphasize collaborative and co-operative learning (Boud, Cohen and Sampson 1999). This cooperation is defined as working together to reach joint goals. (Johnson, Johnson, \& Stanne, 2000).

This tremendous demands change the role of learners to an active role which alters 'assessment oflearning' to 'assessment for learning' (Dysthe 2004). This focuses not only on the assessment itself, but also on the learning, which reveals students' strengths and weaknesses, too.

\subsection{Different Characteristics for New Assessment Methods}

Different characteristics for new assessment methods are introduced by Gipps 1999:

1. Active engagement of the students in the assessment process.

2. Learning process and results should be reflected in the assessment process.

3. Teaching and assessment needs to be connected.

4. Student's engagement and participation should be included.

5. Different skills and higher level thinking must be emphasized.

The way of assessment "intends to improve the quality of learning .... [and] the accreditation of knowledge or performance." (Boud 1990, p. 102). This new setting demands active participation of learners in order to improve learning opportunities. This active engagement in assessment process will promote students' learning (De Wever, Van Keer, Schellens, \& Valcke 2011) as well as promoting 'responsibility towards students' (Gielen, Dochy, \& Onghena 2010). Willem et al. (1993) mentioned the importance of involvement between peers in learning (Shahbodin \& Abd Talib 2012).

\subsubsection{Alternative Assessment}

One of the most effective way for class assessment is alternative assessment (Shepard 2000; Topping 1998). Based on alternative assessment, students' production and integration are evaluated (Macias 1995, cited in Coombe et al. 2007).

\section{Importance of Peer-assessment}

Peer assessment is considered to be one of the main forms of alternative assessment. The importance of peer assessment highlighted in different educational learning and educational research. Slavin (1997) refers to peer-assessment as one of the best and perfect success in educational history. Pedagogically, peer-assessment improves learning of student (Falchikov \& GoldFinch, 2000) through "a sense of ownership and responsibility, motivation, and reflection of the students' own learning" (Saito \& Fujita 2009, p. 151). This form of 
assessment is recommended by Shepard (2000) and Topping (1998) as one of the effective approaches for classroom evaluation. It can also be considered as an opportunity for students as learning facilitator and also used as a tool for instructors to obtain a more clear and obvious picture of learner's performance. (Cheng and Warren 2000). Bandura (1997) refers to the cognitive aspect of assessment and its inevitability.

Wikstorm (2007) refers to peer-assessment as an interactive type of assessment in which learners keep up with their teachers to achieve the goal. In fact teachers are not the only assessors and not more the center of the assessment. Abolfazli Khonbi and Sadeghi (2012, p.48) report that "student-centered approaches in language teaching led the field of language testing to a shift of paradigm from traditional psychometric (teacher - centered) testing to alternative edumetric (student-centered) assessment (Farhady, 2006; McNamara, 2000; Brown \& Hudson, 1998)".

\subsection{Definitions of Peer-Assessment}

Topping (2010, p. 62) defines peer-assessment as "an arrangement for learners to consider and specify the level, value, or quality of a product or performance of other equal-status learners".

Peer-assessment is “an educational arrangement where students judge a peers' performance quantitatively and/or qualitatively and which stimulates students to reflect, discuss and collaborate" (Strijbos \& Sluijsmans 2010, p. 265).

In another definition Robert (2006, p.80) declares peer-assessment as "the process of having the readers critically reflect upon, and perhaps suggest grades for the learning of their peers".

Falchikov (2005, p. 27) refers to another aspect of peer-assessment and reports that in peer-assessment "students use criteria and apply standards to the work of their peers in order to judge that work".

\subsubsection{Differenet Types of Peer-Assessment}

Two types of peer-assessment exist. It has been characterized as either formative or summative. One type of peer-assessment, known as formative assessment, provides feedback and aims at filling the gap between 'current and desired performance' (Sadler 1989). In formative peer-assessment, needs of the learners are of great importance while in summative peer-assessment results are important.

Wen and Tsai (2006, p.28) refer to formative assessment as "students learning needs" and summative peer-assessment as "the needs of the society to evaluate the end result of schooling." In formative assessment instructors will be able to answer the needs of the learners during the learning process and they will be able to focus on different parts which impede their learning, but in summative the result of the teaching and learning process is important. In fact these 2 types of peer-assessment overlap.

\section{Peer-Assessment Usage}

In fact during this process peers play the role of assessors or/and assesses (Van Zundert, 
Sluijsmans, \& van Merriënboer 2010). During this process learners evaluate and judge the quality of performance of other similar status learners (Davies 2006).

According to the procedures of peer-assessment, student-student and student-teacher interactions improve and friend's ideas and opinions will be known better (Butler and Hodge 2001, Falchikov 1995, LeMare and Rubin 1987, McGourty 2000 Sluijsmans et al., 1999). Both teachers and learners are engaged upon dealing with assessment procedures and "have control over the assessment methods, outcomes, and their underlying rationale (Cheng and Warren, 2005)" (Azarnoosh 2013, p. 1).

\section{Scientific Studies of Peer-Assessment}

Different studies revealed the effectiveness of peer-assessment (Lin et al. 2001; Lu and Bol 2007; Richer 1992) and emphasized on its efficacy over peer-tutoring and help seeking (Aleven, Stahl, Schworm, Fischer \& Wallace, 2003). But its efficacy depends on different factors like "students' attitudes, language levels, familiarity with assessing criteria, the type of skill being assessed and the possible presence of bias such as gender and friendship" (Azarnoosh 2013, p. 2).

Some of these factors are not fully recognized, but there are different research on some areas. For instance, Edens et al. (2000) and Langan et al. (2005) reported gender effects, but Sellnow and Trienen (2004) did not. Although Xiao and Lucking (2008) found no influence of peer feedback ratings on learners' attitudes toward peer-assessment, Sullivan et al. (1999) refers to assesses' lack of self-confidence.

According to the Kaufmann and Schunn (2010) some strategies can improve learners' perception towards peer-assessment:

1. More involvement of students in peer-assessment (Sluijsmans et al., 2001; Wen \& Tsai 2006).

2. Providing students with enough training and support (Cheng \& Warren 1997; Boud \& Falchikov 2005, 2007).

3. Make a clarification of peer-assessment criteria (Falchikov 2005; Smith, Cooper, \& Lancaster 2002).

\section{Conclusion}

Although both assessors and assesses will gain benefits by improving their qualifications during the procedures of peer-assessment, some students often doubt on peers' qualifications and knowledge for assessment (Kaufman \& Schunn 2010; Strijbos, Narciss, \& Dünnebier 2010). So based on Kaufman \& Schunn (2010) more studies need to be carried out on students' attitudes and perceptions about peer-assessment.

Although there are some studies discussing the drawbacks and issues in the use and implementation of peer-assessment, there are some studies supporting its importance in the assessment of learners and refer to the positive influence on group work, social skills and also motivation. 


\section{References}

Abolfazli Khonbi, Z., Sadeghi, K. (2012). The Effect of Assessment Type (self vs. peer vs. teacher) on Iranian University EFL Students' Course Achievement. Language Testing in Asia, 2(4), 47-74.

Aleven, V., Stahl, E., Schworm, S., Fischer, F., \& Wallace, R. (2003). Help seeking and help design in interactive learning environments. Review of Educational Research, 73, 277- 320.

Azarnoosh, M. (2013). Peer assessment in an EFL context: attitudes and friendship bias, Language Testing in Asia, 3(11), 1-10.

Bandura, A. (1997). Self-efficacy: The exercise of control. NY: Freeman.

Barbera, E. (2009). Mutual feedback in e-portfolio assessment: an approach to the netfolio system. British Journal of Educational Technology, 40(2), 342-357.

Barrett, H. (2007). Researching electronic portfolios and learner engagement: the reflective initiative. Adolescent and Adult Literacy, 50(6), 436-449.

Boud, D., \& Falchikov, N. (2007). Rethinking assessment in higher education. London: Kogan Page.

Boud, D. J. (1990) Assessment and the promotion of academic values. Studies in Higher Education, 15(1), 101-111.

Boud, D., Cohen, R. and Sampson, J. (1999). Peer learning and assessment. Assessment and Evaluation in Higher Education, 24, 413-426.

Brown, J. D., \& Hudson, T. (1998). The alternatives in language assessment. TESOL Quarterly, 32(4), 653-75.

Butler, S A. \& Hodge, S. R. (2001). Enhancing student trust through peer assessment in physical education. Physical Educator, 58(1), 30-42.

Cheng, W., \& Warren, M. (2005). 'Peer assessment of language proficiency', Language Testing, 22(3), 93-121.

Cheng, W., \& Warren, M. (2000). Making a difference: Using peers to assess individual students' contributions to a group project. Teaching in Higher Education, 5(2), 243-255.

Cheng, Winnie, \& Warren, Martin. (1997). Having second thoughts: Student perceptions before and after peer assessment exercise. Studies in Higher Education, 22(2), 233-239.

Coombe, C., Folse, K., \& Hubly, N. (2007). Assessing English language learners. United State of America: University of Michigan Press.

Davies, P. (2006). Peer assessment: Judging the quality of students' work by comments rather than marks. Innovations in Education and Teaching International, 43(1), 69-82.

De Wever, B., Van Keer, H., Schellens, T., \& Valcke, M. (2011). Assessing collaboration in a wiki: The reliability of university students' peer assessment. The Internet and Higher 
Education, 14(4), 201- 206.

Dysthe, O. (2004, March). The challenges of assessment in a new learning culture. NERA/NFPF 32. Conference Iceland Pedagogical University, Reykjavik, Iceland.

Edens, F., Rink, F., \& Smilde, M. (2000). 'De Studentenrechtbank: een evaluatieonderzoek naar beoordelingslijsten voor presentatievaardigheden. (student court of justice: an evaluation of assessment instruments for presentation skills), Tijdschrift voor Onderwijsresearch, Journal for Educational Research, 24 (3-4): 265-274.

Falchikov, N. (2005). Improving Assessment Through Student Involvement: Practical Solutions for Aiding Learning in Higher and Further Education. New York: RoutledgeFalmer.

Falchikov, N., \& Goldfinch, J. (2000). Student Peer Assessment in Higher Education: A Meta-Analysis Comparing Peer and Teacher Marks. Review of Educational Research, 70(3), 287-322.

Farhady, H. (2006). Twenty five years of living with applied linguistics, collection of articles. Tehran: Rahnama Press.

Gielen, S., Dochy, F., \& Onghena, P. (2010). An inventory of peer assessment diversity. Assessment \& Evaluation in Higher Education, 36, 137-155.

Gipps, C. (1999).Socio-Cultural aspects of assessment. Review of Research in Education, 24, 355-392.

Huerta-Macias, A. (1995). Alternative assessment: Responses to commonly asked questions. TESOL Journal, 5(1), 8-11.

Johnson, D. W., Johnson, R. T., \& Stanne, M. B. (2000). Cooperative learning methods: A meta-analysis. University of Minnescota, Minneopolis, Minnesota. Retrieved June 2, 2010, from:_www.tablelearning.com/uploads/file/EXHIBIT-B.pdf.

Kaufman, J. H., \& Schunn, C. D. (2010). Students' perceptions about peer assessment for writing: their origin and impact on revision work. Instructional Science, 39(3), 387-406.

Langan, A. M., C. P. Wheater, E. M. Shaw, B. J. Haines, W. R. Cullen, J. Boyle, D. Penney, J. Oldekop, C. Ashcroft, L. Lockey, \& R.F. Preziosi. (2005). Peer assessment of oral presentations: effects of student gender, university affiliation and participation in the development of assessment criteria. Assessment and Evaluation in Higher Education, 30, 19-34.

LeMare, L. J., \& Rubin, K. H. (1987). Perspective taking and peer interaction: Structural and Levine, R. E., Kelly, P. A., Karakoc, T., \& Haidet, P. (2007). Peer evaluation in a clinical clerkship: Students' attitudes, experiences, and correlations with traditional assessments. Academic Psychiatry, 31, 19-24.

Lin, S. S. J., Liu, E. Z., \& Yuan, S. M. (2001b). Web peer review: The learner as both adapter and reviewer. IEEE Transactions on Education, 44(3), 246-251. 
Lin, S. S. J., Liu, E. Z., Chiu, C. H., \& Yuan, S. M. (2001a) Web-Based Peer Assessment: attitude and Achievement. IEEE Transaction on Education, 4(2), 211.

Lu, R., \& Bol, L. (2007) A Comparison of Anonymous Versus Identifiable e- Peer Review on College Student Writing Performance and the Extent of Critical Feedback. Journal of Interactive Online Learning, 6, 100-115.

McDowell, L. (1995). The impact of innovative assessment on student learning. Innovation in Education and Training International, 32(4), 302-313.

McGourty, J. (2000). Using multisource feedback in the classroom: a computer-based approach. IEEE.

McNamara, T. (2000). Testing, testing... What is a language test. In H. G. Widdowson (Ed.), Language testing (p. 7). Oxford: Oxford University Press.

Orsmond, P., Merry, S., \& Reiling, K. (2000). The use of student derived marking criteria in peer and self-assessment. Assessment \& Evaluation in Higher Education, 25(1), 23-38.

Pope, N. (2005). The impact of stress in self- and peer assessment. Assessment and Evaluation in Higher Education, 30, 51-63.

Richer, D. L. (1992). The effects of two feedback systems on first year college students writing proficiency. Dissertation Abstracts International, 53(08A), 2722.

Roberts, T. (2006). Self-, peer-, and group assessment in E-learning. United States of America: Information science publishing.

Sadler, D. R. (1989). 'Formative assessment and the design of instructional systems', Instructional Science 18, 119-44.

Saito, H., \& Fujita, T. (2009). Peer-assessing peers' contribution to EFL group presentations. RELC Journal, 40(2), 149-171.

Sellnow, D. D., \& Treinen, K. P. (2004). The role of gender in perceived speaker competence: An analysis of student peer critiques. Communication Education, 53, 286-296.

Shahbodin, F., \& Abd Talib, R. (2012). Designing Animated Pedagogical Agent (APA) to scaffold student learning in online problem Based Learning (PBL). Environment Journal of Engineering, 1(1).

Shepard, Lorrie A. (2000). "The Role of Assessment in a Learning culture" ER Online, October 2000, 29(7), 4-14. http://dx.doi.org/10.3102/0013189X029007004

Slavin, R. E. (1997). Educational psychology: theory and practice (5th ed.). Allyn \& Bacon, Needham Heights, MA.

Sluijsmans, D., Dochy, F., \& Moerkerke, G. (1999). Creating a learning environment by using self-, peer-, and co-assessment. Learning Environments Research, 1, 293-319.

Sluijsmans, D., Moerkerke, G., Van Merriënboer, J., \& Dochy, F. (2001). Peer assessment in 
problem based learning. Studies in Educational Evaluation, 27, 153-73.

Smith, H., Cooper, A., \& Lancaster, L. (2002). Improving the Quality of Undergraduate Peer Assessment: A Case for Student and Staff Development. Innovations in Education and Teaching International, 39(1), 71 - 81.

Strijbos, J. W., \& Sluijsmans, D. (2010). Unravelling peer assessment: Methodological, functional, and conceptual developments. Learning and Instruction, 20(4), 265-269.

Strijbos, J.-W., Narciss, S. \& Dünnebier, K. (2010). Peer feedback content and sender's competence level in academic writing revision tasks: Are they critical for feedback perceptions and efficiency? Learning and Instruction, 20(4), 291-303.

Sullivan, M. E., Hitchcock, M. A., \& Dunnington, G. L. (1999). Peer and self-assessment during problem based tutorials. The American Journal of Surgery, 177(3), 266-269.

Topping, K. (1998). Peer Assessment Between Students in Colleges and Universities. Review of Educational Research, 68(3), 249-276.

Topping, K. J. (2010). Peers as a source of formative assessment. In: H. L. Andrade, \& G. J. Cizek (Eds.), Handbook of formative assessment (pp. 69-75). New York, NY: Routledge.

Van Zundert, M., Sluijsmans, D. M. A., \& Van Merriënboer, J. J. G. (2010). Effective peer assessment processes: Research findings and future directions. Learning and Instruction, 20(4), 270-279.

Wen, M. L. \& Tsai, C. C. (2006). University students' perceptions of and attitudes toward (online) peer assessment. Higher Education, 51(1), 27-44.

Wen, M. L., \& Tsai, C.-C. (2006). University students' perceptions of and attitudes toward (online) peer assessment. Higher Education, 27(18), 27-44.

Wikstorm, N. (2007). Alternative assessment in primary years of international baccalaureate education (Master's thesis).

Xiao Y., \& Lucking, R. (2008). The impact of two types of peer assessment on students' performance and satisfaction within a wiki environment. Internet Higher Educ Internet and Higher Education, 11(3/4), 186-93.

\section{Copyright Disclaimer}

Copyright for this article is retained by the author(s), with first publication rights granted to the journal.

This is an open-access article distributed under the terms and conditions of the Creative Commons Attribution license (http://creativecommons.org/licenses/by/3.0/). 